\title{
Response to "Association between metformin use prior to admission and lower mortality in septic adult patients with diabetes mellitus: beware of potential confounders"
}

\author{
Huoyan Liang, Xianfei Ding and Tongwen Sun ${ }^{*}$ (i)
}

To the Editor:

We thank Dr. Honore and his colleagues for their attention on our study in Critical Care [1]. First, we agree with their point that RRT has a protective effect on the mortality of patients with metformin (MET)-associated lactic acidosis [2]. However, there are some reasons to demonstrate that the lower mortality in septic patients with diabetes is due to MET treatment, rather than the metformin eliminated by RRT. First, the study of Doenyas-Barak et al. [3], one of the included studies in our meta-analysis [1], showed that the use of RRT between the MET-treated population and non-MET users was $38.6 \%$ and $21.2 \%$, but there was no difference between the two groups ( $p=0.13$ ). More importantly, after removing this included study [3], we reworked the pooled effect of the remaining four studies and the result was consistent with our meta-analysis [1]. Furthermore, the study of Jochmans et al. [4] showed the use of RRT is higher in non-MET users than MET users $(18.2 \%$ vs. $17.1 \%)$, but it also indicated that the protective effect of MET use in septic patients with diabetes. In addition, the metformin treatment can improve the liver injury and inflammatory response and even ameliorate the mortality of septic mice in our ongoing experimental study. Finally, we believe that studies in the future to assess the association between metformin and mortality in septic patients with diabetes will be performed.

\footnotetext{
* Correspondence: suntongwen@163.com

General ICU, Henan Key Laboratory of Critical Care Medicine, Zhengzhou Key Laboratory of Sepsis, The First Affiliated Hospital of Zhengzhou University, Zhengzhou 450052, China
}

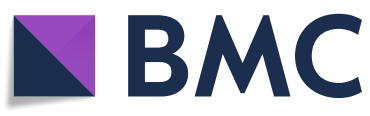

( The Author(s). 2020 Open Access This article is licensed under a Creative Commons Attribution 4.0 International License, which permits use, sharing, adaptation, distribution and reproduction in any medium or format, as long as you give appropriate credit to the original author(s) and the source, provide a link to the Creative Commons licence, and indicate if changes were made. The images or other third party material in this article are included in the article's Creative Commons licence, unless indicated otherwise in a credit line to the material. If material is not included in the article's Creative Commons licence and your intended use is not permitted by statutory regulation or exceeds the permitted use, you will need to obtain permission directly from the copyright holder. To view a copy of this licence, visit http://creativecommons.org/licenses/by/4.0/. The Creative Commons Public Domain Dedication waiver (http://creativecommons.org/publicdomain/zero/1.0/) applies to the data made available in this article, unless otherwise stated in a credit line to the data.
Availability of data and materials

Not applicable.

Ethics approval and consent to participate Not applicable.

\section{Consent for publication}

Not applicable.

\section{Competing interests}

The authors declare that they have no competing interests.

Received: 9 April 2020 Accepted: 24 April 2020

Published online: 06 May 2020

\section{References}

1. Liang H, Ding X, Li L, Wang T, Kan Q, Wang L, Sun T. Association of preadmission metformin use and mortality in patients with sepsis and diabetes mellitus: a systematic review and meta-analysis of cohort studies. Crit Care (London). 2019;23(1):50.

2. Peters N, Jay N, Barraud D, Cravoisy A, Nace L, Bollaert PE, Gibot S. Metformin-associated lactic acidosis in an intensive care unit. Crit Care (London). 2008;12(6):R149.

\begin{abstract}
Funding
This study was supported by the Scientific and Technological Innovation leaders in Central Plains (Grant No. 194200510017), Provincial Ministry Coconstruction Project from Medical Scientific and Technological Research Program of Henan Province (Grant No. SBGJ2018020), and Science and Technology people-benefit project of Zhengzhou (2019KJHM0001).

Acknowledgements

Authors' contributions
LHY and DXF designed the study. STW edited the English text of this manuscript. All authors participated in drafting and reviewing the manuscript. The authors read and approved the final version of the
\end{abstract}


3. Doenyas-Barak K, Beberashvili I, Marcus R, Efrati S. Lactic acidosis and severe septic shock in metformin users: a cohort study. Crit Care (London). 2016;20:10.

4. Jochmans S, Alphonsine JE, Chelly J, Vong LVP, Sy O, Rolin N, Ellrodt O, Monchi M, Vinsonneau C. Does metformin exposure before ICU stay have any impact on patients' outcome? A retrospective cohort study of diabetic patients. Ann Intensive Care. 2017;7(1):116.

\section{Publisher's Note}

Springer Nature remains neutral with regard to jurisdictional claims in published maps and institutional affiliations. 